\title{
Przeciwciała o działaniu immunomodulacyjnym w terapii nowotworów
}

\author{
Michał Marciniec ${ }^{1}$, Andrzej Nowak ${ }^{1}$, Agata Filip ${ }^{2}$
}

Jedną z grup leków immunomodulacyjnych, modyfikujących działanie układu odpornościowego, są przeciwciała monoklonalne. Negatywne receptory, takie jak CTLA-4 i PD-1, obniżają poziom stymulacji komórki, a w opisywanych przypadkach — hamują aktywację i proliferację limfocytów T. Fizjologiczną funkcją tych receptorów jest eliminacja autoreaktywnych komórek odpornościowych, które nie zostały zniszczone w mechanizmie tolerancji centralnej, oraz ochrona tkanek organizmu zmienionych zapalnie. Nowotwory, poprzez ekspresję ligandów dla negatywnych receptorów, unikają rozpoznania przez układ immunologiczny. Działanie przeciwciał obejmuje blokowanie receptorów CTLA-4 i PD-1, przywracając limfocytom zdolność rozpoznawania i reagowania na antygeny nowotworowe. Dotychczasowe badania przeprowadzone nad lekami anty-CTLA, anty-PD-1 i anty-PD-L1 wykazują umiarkowaną skuteczność w leczeniu niektórych zaawansowanych nowotworów, często opornych na leczenie standardowe, połączoną z trwałą remisją guza. Szczególnie korzystne okazało się łączenie dwóch grup leków z efektem synergistycznym. Pomimo zachęcających wyników dotychczasowych badań wciąż przed naukowcami stoją wyzwania, takie jak znalezienie obiektywnych markerów szacujących korzyści leczenia danego pacjenta, zmniejszenie liczby działań niepożądanych oraz normalizacja cen nowych leków.

\section{Immunomodulatory antibodies in cancer therapy}

Among the immunomodulatory drugs modifying the immune system are monoclonal antibodies. Negative receptors, such as Cytotoxic T Cell Antigen 4 (CTLA-4) and Programmed Cell Death protein 1 (PD-1), reduce the level of cell stimulation by other receptors in the cases described. They inhibit the activation and proliferation of T cells. The physiological function of these receptors is the elimination of autoreactive immune cells, which have not been destroyed in the mechanism of central tolerance, and the protection of inflamed tissues in the body. Tumours by expressing negative receptor ligands avoid recognition by the immune system. Antibodies action involves blocking CTLA-4 and PD-1 receptors, restoring the ability of lymphocytes to recognise and respond to tumour antigens. Previous studies of anti-CTLA, anti-PD-1 and anti-PD-L1 drugs are moderately effective in the treatment of some advanced cancers with durable remission of the tumour. It has been proved that it is particularly advantageous to combine the two agents in synergistic effect. Despite the encouraging results of previous studies, it is necessary to find objective markers for estimating the benefits of treatment, to reduce the amount of side effects and normalise the prices of new drugs.

NOWOTWORY Journal of Oncology 2015; 65, 1:42-47

Słowa kluczowe: CTLA-4, PD-1, immunomodulacja, ipilimumab, nivolumab, czerniak, niedrobnokomórkowy rak płuca Key words: CTLA-4, PD-1, immunomodulation, ipilimumab, nivolumab, melanoma, non-small cell lung cancer

${ }^{1}$ Koło Naukowe Genetyki Nowotworów

${ }^{2}$ Zakład Genetyki Nowotworów

Uniwersytet Medyczny w Lublinie 


\section{Wstęp}

Przeciwciała należące do grupy leków immunomodulacyjnych są stosunkowo nową grupą leków przeznaczoną do leczenia nowotworów. Modyfikują one w odpowiedni sposób komórki układu odpornościowego, przywracając im zdolność rozpoznawania i reagowania na antygeny nowotworowe. Immunoterapia ma kilka przewag nad chemioterapią w aspekcie niewielkiej cytotoksyczności w odniesieniu do zdrowych komórek oraz trwałej wyleczalności pacjentów z nawet zaawansowanych nowotworów. Trzeba zachować pewną ostrożność w analizie wyników badań, gdyż leczenie immunologiczne cechuje się dużą zmiennością osobniczą w odpowiedzi na terapię, niekiedy dużym rozciągnięciem w czasie efektów leczenia (liczonym w miesiącach) oraz możliwością przejściowej progresji przed końcową regresją nowotworu [1]. Obecnie temat immunoterapii cieszy się dużym zainteresowaniem wśród badaczy, a do już przebadanych nowotworów z bardzo różnymi rezultatami należą przede wszystkim czerniak, rak płuca i rak nerkowokomórkowy oraz inne, takie jak rak piersi, okrężnicy, jajnika i liczne nowotwory hematologiczne [2].

\section{Podstawowe informacje kliniczne o receptorach i ligandach}

Aby wyjaśnić mechanizm działania leków, trzeba zacząć od przedstawienia receptorów, jakie mają największe znaczenie w immunomodulacji. Są to receptory: pozytywny CD28 oraz negatywne CTLA-4 (Cytotoxic T Cell Antigen 4) i PD-1 (Programmed Cell Death Protein 1) wraz z ligandem PD-L1. Wszystkie powyższe receptory ulegają ekspresji na limfocytach T (ryc. 1).

Funkcja receptora CD28 jest bardzo dobrze poznana. Działa on jako koreceptor przekazujący sygnał aktywacji i proliferacji limfocytów T. Główny szlak aktywacji komórekT

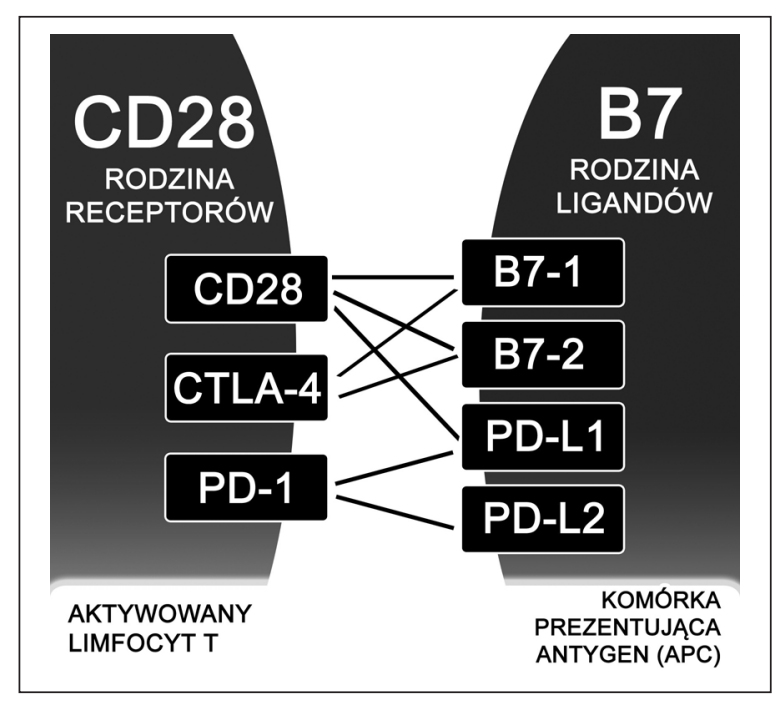

Rycina 1. Receptory i ich ligandy prowadzi jednak przez receptor TCR (TCell Receptor) — jest on pobudzany przez komórki prezentujące antygen za pomocą MHC (Major Histocompatibility Complex). Zarówno CD28, jak i TCR są niezbędne do aktywacji limfocytu T.

Najogólniej można stwierdzić, że funkcja receptorów CTLA-4 i PD-1 polega na hamowaniu aktywności i proliferacji limfocytów T. Skoro komórki te spełniają bardzo pożyteczną rolę walki z obcymi antygenami w przebiegu infekcji, to czy potrzebne jest hamowanie ich aktywności? Okazuje się, że tak. Po pierwsze, każdy proces w organizmie wymaga równowagi. Niedopuszczalna jest sytuacja, w której nadmierna aktywacja limfocytów T powoduje ich nieograniczoną proliferację przechodzącą w proliferację nowotworową lub skutkuje wytworzeniem form autoagresywnych. Takiej sytuacji zapobiegają limfocyty regulatorowe (dawna nazwa - „supresorowe") oraz omawiane w tym artykule negatywne receptory CTLA-4 i PD-1. Po drugie, komórkiT autoreaktywne powinny ulec zniszczeniu w procesie tolerancji centralnej w grasicy - mechanizm ten nie jest jednak niezawodny i czasem dochodzi do uwolnienia autoreaktywnych komórek do krwi, a wtedy do akcji wkracza proces tolerancji obwodowej, w którym receptor PD-1 blokuje aktywację limfocytu T przez komórkę prezentującą autoantygen [3]. Po trzecie, zbyt nasilona reakcja limfocytów $T$ w zmienionej zapalnie tkance mogłaby doprowadzić do jej zniszczenia, czemu również zapobiegają CTLA-4 i PD-1. Udowodniono także rolę negatywnych receptorów w zapobieganiu immunizacji matki antygenami płodu [4]. Brak tych receptorów prowadzi do licznych zaburzeń przedstawionych w dalszej części artykułu.

Pomimo tego, że oba receptory są receptorami negatywnymi, opisano wiele różnic pomiędzy nimi. Najważniejsze $z$ nich to to, że:

- zarówno CTLA-4 jak i PD-1 ulegają ekspresji na aktywnych limfocytach T, natomiast CTLA-4 dodatkowo na limfocytach T pamięci i regulatorowych, a PD-1 na „wyczerpanych" limfocytach T (np. po przedłużającej się infekcji) [2];

- CTLA-4 działa bardziej „centralnie” (np. w węźle chłonnym), zapobiegając aktywacji i proliferacji limfocytówT, natomiast PD-1 bardziej „dystalnie” (np. w tkankach obwodowych), ograniczając tam destrukcyjne funkcje limfocytów (ryc. 2) [3];

- PD-1 wpływa również na odpowiedź humoralną, regulując przetrwanie limfocytów B w ośrodkach rozmnażania, oraz wpływa na ilość i jakość długo żyjących komórek plazmatycznych, natomiast nie wpływa na różnicowanie się limfocytów B [5];

- szlak wewnątrzkomórkowy CTLA-4 działa w oparciu o PP2A (Protein Phosphatase 2), natomiast PD-1 wykorzystuje SHP-1 i 2 (Src Homology region 2 domain-containing Phosphatase).

Ligandy opisywanych receptorów należą do rodziny B7. Warto zauważyć, że ten sam ligand, np. B7-1, może być 


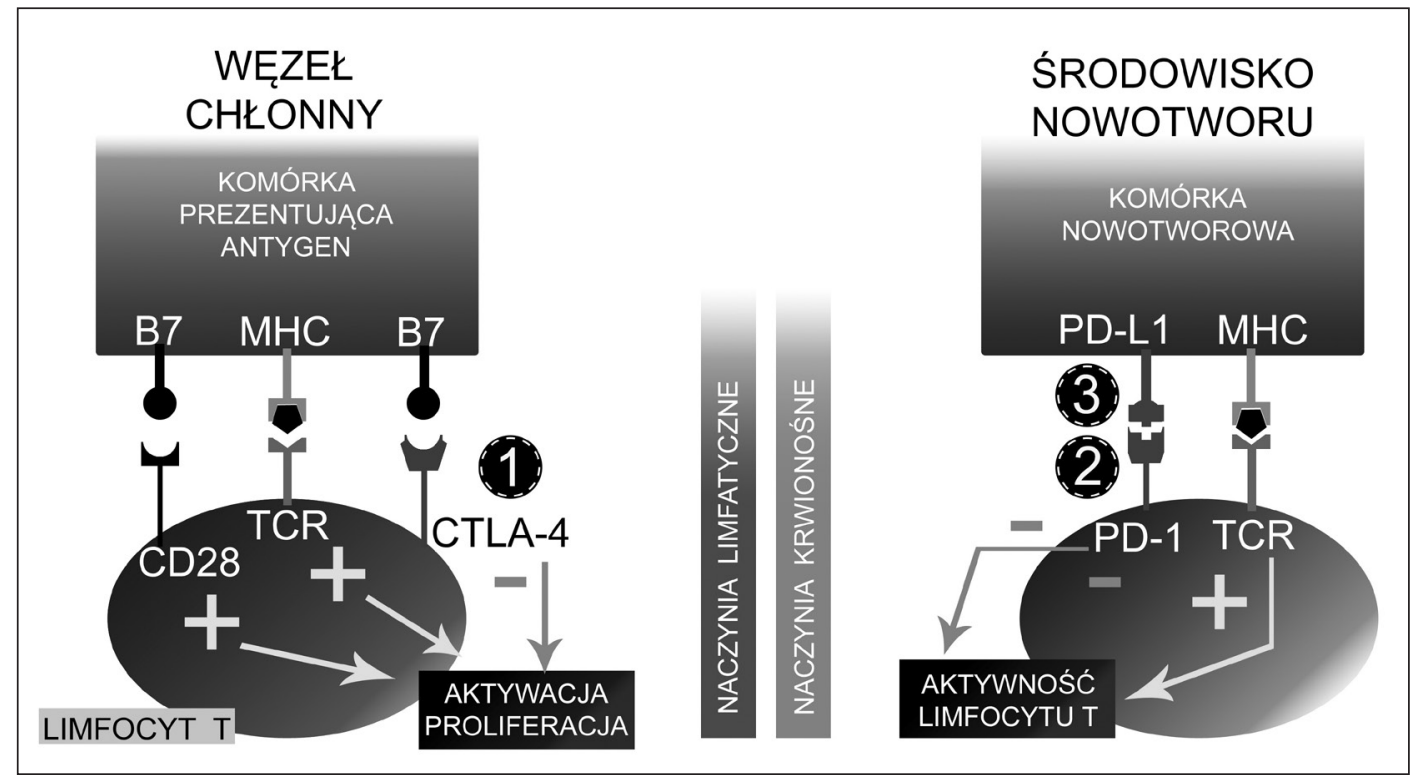

Rycina 2. Mechanizm działania leków (blokowane receptory). 1 - ipilimumab, tremelimumab; 2 - nivolumab, lambrolizumab, pidilizumab; 3-BMS-936559, MEDI4736, MPDL3280A

związany przez dwa odmienne receptory, zarówno pozytywny CD28, jak i negatywny CTLA-4. Receptor CTLA-4 ma większe powinowactwo do B7-1, ale również mniejszą gęstość powierzchniową w błonie komórki. Współzawodnictwo o receptor ma znaczenie, gdy sygnał z TCR staje się coraz słabszy, zapobiegając wtedy nadmiernej stymulacji antygenami limfocytów T (np. podczas procesu zdrowienia z infekcji) [2].

Ekspresja PD-L1 zachodzi zarówno na komórkach układu immunologicznego (komórki dendrytyczne, makrofagi, limfocyty T i B), jak i na tkankach niehematopoetycznych - w różnych narządach, w śródbłonku i nabłonku, natomiast jego występowanie na komórkach nowotworowych jest patologią. Praktycznie wszystkie komórki nowotworowe wytwarzają specyficzne białka antygenowe pod wpływem zmian genetycznych lub epigenetycznych, wykorzystując PD-L1 w takim samym celu jak tkanki zmienione zapalnie: do ochrony samych siebie przed limfocytami T [6]. W niektórych komórkach nowotworowych, w których PD-L1 uległ ekspresji, stwierdzono zwiększoną oporność na apoptozę. Tak więc PD-L1 może również działać jako receptor negatywny apoptozy [7].

\section{Mechanizm działania leków}

Przeciwciała monoklonalne przeciwko receptorom negatywnym CTLA-4 lub PD-1 powodują zniesienie ich hamującego wpływu na limfocyty T. W przypadku PD-1 ten sam efekt można osiągnąć poprzez blokowanie liganda PD-L1 przeciwciałami, co stało się trzecim „punktem uchwytu” dla leków immunomodulujących (ryc. 2). Oprócz leczenia nowotworów leki te są także z powodzeniem wykorzysty- wane w eksperymentalnych terapiach leczenia zakażeń HIV, powodując znaczne obniżenie wiremii [8]. Tabela I przedstawia opisywane leki wraz z mechanizmem ich działania oraz aktualne badania w fazie III, prowadzone głównie w USA.

\section{Czy są choroby indukowane brakiem CTLA-4 i PD-1?}

Taką hipotezę wysnuli badacze już w latach 90., udowadniając, że myszy z rekombinowanym genomem pozbawionym genów receptora CTLA-4, umierały po 3-4 tygodniach z powodu ciężkich, ogólnych chorób autoimmunologicznych (jak już wspomniano, CTLA-4 działa bardziej "centralnie") [9]. Z kolei brak genów dla PD-1 skutkował również pojawieniem się chorób autoimmunologicznych, ale były one specyficzne narządowo (działanie „dystalne") i występowały w znacznie późniejszym wieku, pozwalając myszom na początkowo normalny rozwój [10]. Do tych chorób zalicza się przede wszystkim zespoły toczniopodobne, glomerulopatie oraz kardiomiopatie z przeciwciałami przeciwko troponinie I [11, 12]. Należy jednak pamiętać o tym, że - w przeciwieństwie do usunięcia genów — blokowanie receptora przeciwciałami w określonych dawkach nie powoduje aż tak poważnych reakcji autoimmunologicznych [13].

\section{Dotychczasowe badania}

Przeprowadzono wiele badań leków immunomodulacyjnych, wyniki największych z nich zostały przestawione w tabeli II. Już przy wstępnej analizie danych widoczna jest grupa nowotworów występująca szczególnie często w analizach - są to: czerniak, niedrobnokomórkowy rak płuca oraz rak nerkowokomórkowy. W tych nowotworach 
Tabela I. Przykłady leków immunomodulacyjnych i aktualnych badań. Na podstawie http://www.clinicaltrials.gov (dostęp z dnia 27.09 .2014 r.)

\begin{tabular}{|c|c|c|c|c|}
\hline Nazwa leku & Rodzaj przeciwciał & Działanie & $\begin{array}{c}\text { Obecna liczba badań } \\
\text { w fazie III }\end{array}$ & $\begin{array}{c}\text { Nowotwory } \\
\text { badane w III fazie }\end{array}$ \\
\hline Ipilimumab & lgG1 ludzkie & anty-CTLA-4 & 14 & $\begin{array}{l}\text { Czerniak, } \mathrm{SCLC}, \mathrm{NSCLC}, \mathrm{RCC}, \\
\text { rak prostaty }\end{array}$ \\
\hline Tremelimumab & lgG2 ludzkie & anty-CTLA-4 & $\begin{array}{c}0 \\
\text { (faza II dla NSCLC } \\
\text { i międzybłoniaka opłucnej) }\end{array}$ & - \\
\hline Nivolumab & lgG4 ludzkie & anty-PD-1 & 12 & $\begin{array}{c}\text { czerniak, NSCLC, glioblastoma, } \\
\text { RCC }\end{array}$ \\
\hline $\begin{array}{l}\text { Lambrolizumab } \\
\text { Pembrolizumab }\end{array}$ & IgG4 humanizowane & anty-PD-1 & 4 & czerniak, NSCLC \\
\hline Pidilizumab & IgG1 humanizowane & anty-PD-1 & $\begin{array}{c}0 \\
\text { (faza II dla chłoniaków i glejaka) }\end{array}$ & - \\
\hline BMS-936559 & lgG4 ludzkie & anty-PD-L1 & $\begin{array}{c}0 \\
\text { (faza I dla nowotworów } \\
\text { hematologicznych) }\end{array}$ & - \\
\hline MEDI4736 & lgG1 ludzkie & anty-PD-L1 & 2 & NSCLC \\
\hline MPDL3280A & lgG1 ludzkie & anty-PD-L1 & 1 & NSCLC \\
\hline
\end{tabular}

Tabela II. Rezultaty badań przeprowadzonych na lekach immunomodulacyjnych

\begin{tabular}{|c|c|c|c|c|}
\hline Faza badania & Próba & Nowotwór & ORR & Badanie \\
\hline \multicolumn{5}{|l|}{ Ipilimumab } \\
\hline III & 676 & czerniak & $10,9 \%$ & Hodi FS, 2010 [14] \\
\hline III & 502 & czerniak & $15,2 \%$ & Robert C, 2011 [15] \\
\hline II & 204 & NSCLC & ok. $22 \%$ & Lynch TJ, 2012 [16] \\
\hline II & 61 & $\mathrm{RCC}$ & ok. $10 \%$ & Yang JC, 2007 [17] \\
\hline \multicolumn{5}{|l|}{ Tremelimubab } \\
\hline III & 655 & czerniak & $10,7 \%$ & Ribas A, 2013 [18] \\
\hline ॥ & 87 & NSCLC & $2,3 \%$ & Zatloukal P, 2009 [32] \\
\hline II & 47 & rak okrężnicy & $2 \%$ & Chung KY, 2010 [27] \\
\hline II & 29 & międzybłoniak opłucnej & $13,8 \%$ & Calabro L, 2014 [33] \\
\hline \multicolumn{5}{|l|}{ Nivolumab } \\
\hline \multirow[t]{5}{*}{$\mathrm{I} / \mathrm{II}$} & 296 & czerniak & $27,6 \%$ & Topalian SL, 2012 [19] \\
\hline & & NSCLC & $18,4 \%$ & \\
\hline & & rak prostaty & $0 \%$ & \\
\hline & & $\mathrm{RCC}$ & $27,3 \%$ & \\
\hline & & rak okrężnicy & $0 \%$ & \\
\hline I & 107 & czerniak & $31 \%$ & Sznol M, 2013 [20] \\
\hline \multirow[t]{3}{*}{ I } & 262 & czerniak & $31 \%$ & Topalian SL, 2013 [21] \\
\hline & & NSCLC & $16 \%$ & \\
\hline & & $\mathrm{RCC}$ & $29 \%$ & \\
\hline \multicolumn{5}{|c|}{ Pembrolizumab } \\
\hline I & 135 & czerniak & $38 \%$ & Hamid O, 2013 [22] \\
\hline 1 & 173 & czerniak & $26 \%$ & Robert C, 2014 [23] \\
\hline \multicolumn{5}{|l|}{ Pidilizumab } \\
\hline ॥ & 32 & chłoniak grudkowy & $66 \%$ & Westin JR, 2014 [28] \\
\hline II & 66 & chłoniak rozlany z dużych komórek B & $51 \%$ & Armand P, 2013 [29] \\
\hline \multicolumn{5}{|l|}{ BMS-936559 } \\
\hline \multirow[t]{4}{*}{1} & 161 & czerniak & $17 \%$ & Brahmer JR, 2012 [24] \\
\hline & & NSCLC & $10 \%$ & \\
\hline & & rak jajnika & $6 \%$ & \\
\hline & & $\mathrm{RCC}$ & $12 \%$ & \\
\hline \multicolumn{5}{|l|}{ MPDL3280A } \\
\hline I & 45 & czerniak & $29 \%$ & Herbst RS, 2013 [25] \\
\hline I & 52 & NSCLC & $22 \%$ & Spigel DR, 2013 [26] \\
\hline
\end{tabular}


odsetek pozytywnych odpowiedzi (ORR) zwykle waha się w granicach 10-30\% [14-26]. Nie są to zbyt wysokie wartości, jednak należy pamiętać, że na ogół i tak przewyższają wyniki standardowej chemioterapii ze względu na końcowe stadia zaawansowania nowotworów, często z przerzutami lub stwierdzoną opornością na poprzednie leczenie. Tak jak wspomniano już wcześniej, większość remisji była długotrwała, liczona w latach. Nie udało się natomiast udowodnić wyższości leków immunomodulacyjnych w terapii raka okrężnicy z ORR w granicach 0-2\% [19, 27], natomiast najwyższymi wartościami ORR, większymi niż $50 \%$ odznaczały się chłoniaki [28, 29]. Niekiedy niskie wartości pozytywnych odpowiedzi można tłumaczyć zbyt rzadkim schematem dawkowania, np. 1 dawka na 3 miesiące, chociaż zbyt częste dawkowanie również nie przynosi korzyści - trzeba wówczas przerywać leczenie w celu podania środków immunosupresyjnych [14].

\section{Działania niepożądane leków}

Działania niepożądane zależne od przeciwciał zwykle pojawiają się 8-10 tygodni po rozpoczęciu terapii i objawiają się najczęściej reakcjami skórnymi (wysypka, świąd), nieswoistymi zapaleniami jelit oraz zwiększonym poziomem enzymów wątrobowych [1]. Nie są one poważne, jednak występują stosunkowo często (nawet do 60\%, bardzo duże rozbieżności w poszczególnych badaniach). Sytuacje, w których działania niepożądane powodowały śmierć lub wykluczenie danego pacjenta z grupy badawczej, zdarzały się jedynie sporadycznie.

\section{Czy korzystne jest połączenie leków anty-CTLA-4 $\mathrm{i}$ anty-PD-1?}

Zdecydowanie najbardziej obiecujące wyniki badań uzyskano w przypadku jednoczesnego stosowania blokerów CTLA-4 i PD-1. W jednym z badań, w grupie 53 pacjentów otrzymujących taką terapię, ORR wyniósł aż 40\%, a połowa z nich doświadczyła szybkiej i trwałej redukcji guza o ponad 80\% [30]. Wiązało się to także z większą liczbą działań niepożądanych 3 i 4 stopnia (53\%, ponad dwukrotnie więcej niż stosowanie leków oddzielnie), aczkolwiek w większości były one odwracalne. Dostępne są również inne badania potwierdzające synergię leków. 10-procentową skuteczność dla leku anty-CTLA-4 oraz 25-procentową skuteczność dla anty-PD-1 zestawiono z nawet 65-procentową odpowiedzią na leczenie przy jednoczesnym ich stosowaniu [31]. Zachęcające wyniki badań stały się podstawą do ich kontynuacji w kolejnych fazach.

\section{W poszukiwaniu markera}

Niestety, nie znaleziono jeszcze wskaźnika, który pozwoliłby przed rozpoczęciem leczenia sprawdzić, czy dany pacjent pozytywnie odpowie na terapię. W przypadku CTLA-4 jako biomarker skuteczności postulowano bez- względną liczbę limfocytów (ALC, Absolute Lymphocyte Count) mierzoną po 2 dawkach ipilimumabu, gdzie poziom $\mathrm{ALC} \geq 1000 / \mu \mathrm{L}$ wskazywał na znacznie lepsze wyniki leczenia [13]. Badanie było jednak przeprowadzone na niewielkiej, 53-osobowej grupie pacjentów. W przypadku szlaku PD-1/PD-L1 sądzono, że wystarczy zbadać poziom ekspresji liganda na komórkach nowotworowych — im jest on większy, tym lepszego wyniku terapii należałoby się spodziewać. Niestety, obecnie nie ma nawet badań, które potwierdziłyby spodziewany całkowity brak skuteczności leczenia guzów z ekspresją PD-L1 równą 0\% [1]. Tak więc znalezienie odpowiednich markerów będzie dla przyszłych badaczy jednym z priorytetowych zadań.

\section{Podsumowanie}

Lokalizacja receptorów PD-1 przeważnie w środowisku guza, a CTLA-4 w centralnym układzie limfatycznym przemawia za większą rolą PD-1 w leczeniu guzów litych przy mniejszych immunozależnych działaniach niepożądanych, więc potencjalnie to ten receptor jest lepszym celem badań. Jednak to właśnie lek anty-CTLA-4, ipilimumab, w następstwie korzystnych wyników badań został dopuszczony w Polsce do użytku klinicznego w 2014 roku [3]. Również większe ORR notowano w przypadku blokerów szlaku PD-1/PD-L1 w porównaniu z CTLA-4. Ogólnie odsetki pozytywnych odpowiedzi w badaniach nad przeciwciałami z grupy leków immunomodulacyjnych nie należą do największych, ale są w większości przypadków długotrwałe. Do tej grupy nie wlicza się przypadków, w których choroba uległa ustabilizowaniu, co również jest rozpatrywane jako korzyść wynikająca z terapii. Ważne jest, aby odpowiednio dobrać markery, za pomocą których będzie można wyłonić pacjentów najbardziej podatnych na leczenie, co teoretycznie powinno znacznie zwiększyć odsetek pozytywnych odpowiedzi. Być może jeszcze większy efekt synergistyczny od połączenia dwóch leków wykaże terapia trójlekowa lub z łączną większą liczbą leków. W takim przypadku należy rozwiązać dwa najważniejsze problemy: wzrastającą ilość działań niepożądanych oraz szybujące w górę ceny nowych leków.

\section{Lista stosowanych skrótów}

RCC - Renal Cell Carcinoma, rak nerkowokomórkowy SCLC — Small Cell Lung Cancer, drobnokomórkowy rak płuca NSCLC — Non-Small Cell Lung Cancer, niedrobnokomórkowy rak płuca

Konflikt interesów: nie zgłoszono

\section{Michał Marciniec}

e-mail:apexpulmonis@gmail.com

Otrzymano: 17 lipca $2014 \mathrm{r}$.

Przyjęto do druku: 21 października 2014 r. 


\section{Piśmiennictwo}

1. Naidoo J, Page DB, Wolchok JD. Immune modulation for cancer therapy. Brit J Cancer 2014. Online publication; doi: 10.1038/bjc.2014.348.

2. Intlekofer $\mathrm{AM}$, Thompson $\mathrm{CB}$. At the bench: preclinical rationale for CTLA-4 and PD-1 blockade as cancer immunotherapy. J Leukoc Biol 2013; 94: 25-39.

3. Pedoeem A, Azoulay-Alfaguter I, Strazza M i wsp. Programmed death-1 pathway in cancer and autoimmunity. Clin Immunol 2014; 153: 145-152.

4. Guleria I, Khosroshahi A, Ansari MJ i wsp. A critical role for the programmed death ligand 1 in fetomaternal tolerance. JEM 2005; 202: 231-237.

5. Good-Jacobson KL, Szumilas CG, Chen Li wsp. PD-1 regulates germinal center B cell survival and the formation and affinity of long-lived plasma cells. Nat Immunol 2010; 11: 535-542.

6. Topalian SL, Drake CG, Pardoll DM. Targeting the PD-1/B7-H1 (PD-L1) pathway to activate anti-tumor immunity. Curr Opin Immunol 2012; 24: 207-212

7. Azuma T, Yao S, Zhu G i wsp. B7-H1 is a ubiquitous antiapoptotic receptor on cancer cells. Blood 2008; 111: 3635-3643.

8. Nicholas KJ, Zern EK, Barnett L i wsp. B cell responses to HIV antigen are a potent correlate of viremia in HIV-1 infection and improve with PD-1 blockade. PloS One 2013; 8: e84185.

9. Waterhouse P, Penninger JM, Timms E i wsp. Lymphoproliferative disorders with early lethality in mice deficient in Ctla-4. Science 1995; 270: 985-988.

10. Nishimura H, Nose M, Hiai H i wsp. Development of lupus-like autoimmune diseases by disruption of the PD-1 gene encoding an ITIM motif-carrying immunoreceptor. Immunity 1999; 11: 141-151.

11. Blank C, Mackensen A. Contribution of the PD-L1/PD-1 pathway to T-cell exhaustion: an update on implications for chronic infections and tumor evasion. Cancer Immunol Immunother 2007; 56: 739-745.

12. Okazaki T, Tanaka Y, Nishio R i wsp. Autoantibodies against cardiac troponin I are responsible for dilated cardiomyopathy in PD-1-deficient mice. Nat Med 2003; 9: 1477-1483.

13. Ku GY, Yuan J, Page DB i wsp. Single-institution experience with ipilimumab in advanced melanoma patients in the compassionate use setting. Cancer 2010; 116: 1767-1775.

14. Hodi FS, O'Day SJ, McDermott DF i wsp. Improved survival with ipilimumab in patients with metastatic melanoma. N Eng J M 2010; 363: 711-723.

15. Robert C, Thomas L, Bondarenko I i wsp. Ipilimumab plus dacarbazine for previously untreated metastatic melanoma. N Eng J M 2011; 364: 2517-2526.

16. Lynch T. J, Bondarenko I, Luft A i wsp. Ipilimumab in combination with paclitaxel and carboplatin as first-line treatment in stage IIIB/IV non-small-cell lung cancer: Results from a randomized, double-blind, multicenter phase II study. J Clin Oncol 2012; 30: 2046-2054.

17. Yang J. C, Hughes M, Kammula U i wsp. Ipilimumab (anti-CTLA4 antibody) causes regression of metastatic renal cell cancer associated with enteritis and hypophysitis. J Immunother 2007; 30: 825.

18. Ribas A, Kefford R, Marshall M. A i wsp. Phase III randomized clinical trial comparing tremelimumab with standard-of-care chemotherapy in patients with advanced melanoma. J Clin Oncol 2013; 31: 616-622.
19. Topalian SL, Hodi FS, Brahmer JR i wsp. Safety, activity, and immune correlates of anti-PD-1 antibody in cancer. N Eng J M 2012; 366: 2443-2454.

20. Sznol M, Kluger HM, Hodi FS i wsp. Survival and long-term follow-up of safety and response in patients (pts) with advanced melanoma (MEL) in a phase I trial of nivolumab (anti-PD-1; BMS-936558; ONO-4538). J Clin Oncol 2013; 31: (Suppl).

21. Topalian S. L, Sznol M, Brahmer JR i wsp. Nivolumab (anti-PD-1; BMS 936558; ONO-4538) in patients with advanced solid tumors: Survival and long-term safety in a phase I trial. J Clin Oncol 2013; 31: S 3002.

22. Hamid O, Robert C, Daud A i wsp. Safety and tumor responses with lambrolizumab (anti-PD-1) in melanoma. NEng JM 2013;369: 134-144.

23. Robert C, Ribas A, Wolchok JD i wsp. Anti-programmed-death-receptor-1 treatment with pembrolizumab in ipilimumab-refractory advanced melanoma: a randomised dose-comparison cohort of a phase 1 trial. Lancet 2014; 384: 1109-1117.

24. Brahmer JR, Tykodi SS, Chow LQ i wsp. Safety and activity of anti-PD-L1 antibody in patients with advanced cancer. N Eng J M 2012; 366: 2455-2465.

25. Herbst RS, Gordon MS, Fine GD i wsp. A study of MPDL3280A, an engineered PD-L1 antibody in patients with locally advanced or metastatic tumors. J Clin Oncol 2013; 31: a3000.

26. Spigel DR, Gettinger SN, Horn L i wsp. Clinical activity, safety, and biomarkers of MPDL3280A, an engineered PD-L1 antibody in patients with locally advanced or metastatic non-small cell lung cancer (NSCLC). J Clin Oncol 2013; 31: (suppl.), abstract 8008.

27. Chung K. Y, Gore I, Fong L i wsp. Phase II study of the anti-cytotoxic T-lymphocyte-associated antigen 4 monoclonal antibody, tremelimumab, in patients with refractory metastatic colorectal cancer. J Clin Oncol 2010; 28: 3485-3490.

28. Westin J. R, Chu F, Zhang M i wsp. Safety and activity of PD1 blockade by pidilizumab in combination with rituximab in patients with relapsed follicular lymphoma: a single group, open-label, phase 2 trial. Lancet Oncol 2014; 15: 69-77.

29. Armand P, Nagler A, Weller EA i wsp. Disabling immune tolerance by programmed death-1 blockade with pidilizumab after autologous hematopoietic stem-cell transplantation for diffuse large B-cell lymphoma: results of an international phase II trial. J Clin Oncol 2013; 31: 4199-4206.

30. Wolchok JD, Kluger H, Callahan MK i wsp. Nivolumab plus ipilimumab in advanced melanoma. New England Journal of Medicine 2013; 369: 122-133.

31. Curran MA, Montalvo W, Yagita H i wsp. PD-1 and CTLA-4 combination blockade expands infiltrating $T$ cells and reduces regulatory $T$ and myeloid cells within B16 melanoma tumors. Proc Natl Acad Sci 2010; 107: 4275-4280.

32. Zatloukal P, Heo DS, Park K i wsp. Randomized phase II clinical trial comparing tremelimumab (CP-675,206) with best supportive care (BSC) following first-line platinum-based therapy in patients (pts) with advanced non-small cell lung cancer (NSCLC). J Clin Oncol 2009; 27: 8071.

33. Calabro L, Morra A, Fonsatti F i wsp. A phase 2 single-arm study with tremelimumab at an optimized dosing schedule in second-line mesothelioma patients. J Clin Oncol 2014; 32: 5. 